\title{
Of Church Orders and
}

\section{Postmodernism}

\section{The Convent of Wesel, the Construction of the Dutch Reformed \\ Church Order and the History and Nature of History}

\author{
PHILIP BENEDICT
}

Self-avowedly influenced by the postmodernist critique of nineteenth-century 'positivism', Jesse Spohnholz's ambitious and multiple prize-winning 2017 The Convent of Wesel: The Event that Never was and the Invention of Tradition speaks at once to the political and institutional history of the Reformed churches of the Netherlands and northwestern Germany, to the role of archiving practices in shaping historical understanding, and to the nature of historical study. This review offers both an extended synopsis and a critique of the book. While recognizing its considerable achievement, it questions its framing of its findings about the Reformation era with reference to the 'confessionalization' debate, its reliance on a prefabricated narrative about archives as instruments of power and marginalization, and its mischaracterizations of post-Rankean historical practice and theory. Implications of the book's findings for further research into the politics and personalities of the Reformation in the Low Countries are also suggested.

Met zijn ambitieuze en prijswinnende boek The Convent of Wesel: The Event that Never was and the Invention of Tradition (Cambridge 2017) raakt Jesse Spohnholz, onder zelfverklaarde invloed van de postmodernistische kritiek op het negentiende-eeuwse 'positivisme', zowel aan de politieke en institutionele geschiedenis van gereformeerde kerken in Nederland en Noordwest-Duitsland, de rol van archivalische praktijken in het vormgeven van de historische interpretatie, en aan de aard van historisch onderzoek. Deze recensie bevat zowel een uitgebreide samenvatting van, als een kritiek op het boek. Terwijl de aanzienlijke verdiensten van het boek erkend worden, worden ook drie punten van kritiek besproken: 
de manier waarop de auteur zijn onderzoeksresultaten over de Reformatie presenteert en dit vooral in relatie tot het debat over confessionalisering, het vertrouwen van de auteur in een vooraf geconstrueerd narratief over het archief als machtsinstrument, en de verkeerde karakterisering van post-Rankeaanse historische praktijken en theorie. Tot slot biedt deze recensie op basis van de implicaties van de onderzoeksresultaten van dit boek suggesties voor vervolgonderzoek naar de politiek en de actoren van de Reformatie in de Lage Landen.

Jesse Spohnholz's The Convent of Wesel: The Event that Never was and the Invention of Tradition (Cambridge University Press 2017) is an ambitious and unusually stimulating book that has received uniformly positive reviews and won prizes from the American Society for Church History and the DAAD/German Studies Association. Part One is an outstanding exercise in multi-archival historical scholarship that proposes a convincing solution to a twin mystery of which a few specialists in the history of the Dutch Reformation have been aware for at least a generation, that of whether the so-called Convent of Wesel, an assembly long believed to be of importance for the early institutional history of the Reformed Church in the Netherlands and northwest Germany, actually met in the city of Cleves in 1568; if it did not, what then was the true nature of the surviving document that historians long believed to contain its decisions? Spohnholz demonstrates that it is overwhelmingly probable that no substantial meeting of churchmen took place in Wesel in 1568 and suggests another interpretation of the document.

Part Two then combines the story of the archiving of surviving copies of the Wesel articles with the history of the historiography of the topic to reconstruct how historians came to think that a synod-like gathering had taken place and even to credit it with such importance that the 3ooth anniversary of the non-event was commemorated in Wesel with a multi-day 'jubilee of the foundation of the Presbyterian system'. Spohnholz casts this half of the book as nothing less than 'a study of the nature of historical inquiry itself' (page 5). Its account of how historians and archivists collaborated in unwittingly making and then slowly unmaking a historical myth about the Convent of Wesel provides an illuminating case study of how historical knowledge about a specific topic changes over time.

Yet The Convent of Wesel is also a flawed book. 'I have drawn on a kind of postmodernist critique of nineteenth-century positivism', the author states in the Conclusion (page 239). 'The book is informed by the argument that all knowledge is embedded in power relationships that inherently marginalize some and privilege others'. In fact, The Convent of Wesel is anything but a postmodern history. At its core, it is a work of critical historical scholarship using methods that Lorenzo Valla would recognize and ending with conclusions about the nature of history that most historians of previous generations would find uncontroversial. Here and there, however, topoi of 
postmodernism are introduced. When they are, they nearly always muddy the waters or cause the analysis to veer off track. As Sarah Maza has noted, the bitter polemics that erupted in the 1990 when postmodern currents first made important inroads into the profession have now largely died down, as many historians have borrowed insights from the trend, while keeping 'experimental and theoretical work [...] confined to the margins of the discipline'. ${ }^{1}$ If certain ideas of postmodernism are indeed well on their way to being normalized, as this book suggests, the resulting costs in historical and conceptual confusion may justify renewed attention to them.

Furthermore, because the book's Conclusion is overwhelmingly devoted to the largest questions about the nature of history raised by postmodern critiques, the portion of the book that focuses on the religious history of the sixteenth century remains little more than a dismantling of one part of an old narrative about the history of Dutch Reformed church institutions. Its few broader reflections about the implications of the book's findings for our understanding of larger themes within the history of the sixteenth century relate these findings to the debate about 'confessionalization' that has all but monopolized the attention of historians of the Reformation since the 1980s. As I shall explain further along, this is simply not the appropriate interpretive frame in which to place Part One's reinterpretation of the Wesel Convent. A more constructive use of the author's findings and expertise would have been to explore how his new view of this event changes established understandings of the Reformed church's institutional development in the Netherlands and beyond. Only a few brief sentences in the book speculate about this. These misconstrue a key point about the emergence of presbyterian church government in northwestern Europe.

In light of the overwhelmingly positive reception so far received by The Convent of Wesel, the importance of the questions it tackles concerning the nature and history of historical scholarship, and the doors concerning the politics and process of the Dutch Reformation that it opens but then does not pass through, an extended critical examination highlighting its problematic features seems merited.

\section{What Was and Was Not 'Done at Wesel, November 3, 1568'}

A longstanding historiographic legend asserts that some sixty Reformed pastors and laymen, representing both the churches under the cross functioning secretly inside the Seventeen Provinces and the refugee churches 


\title{
The Convent of Wesel
}

\author{
The Event that Never was \\ and the Invention of Tradition
}

\section{Jesse Spohnholz}

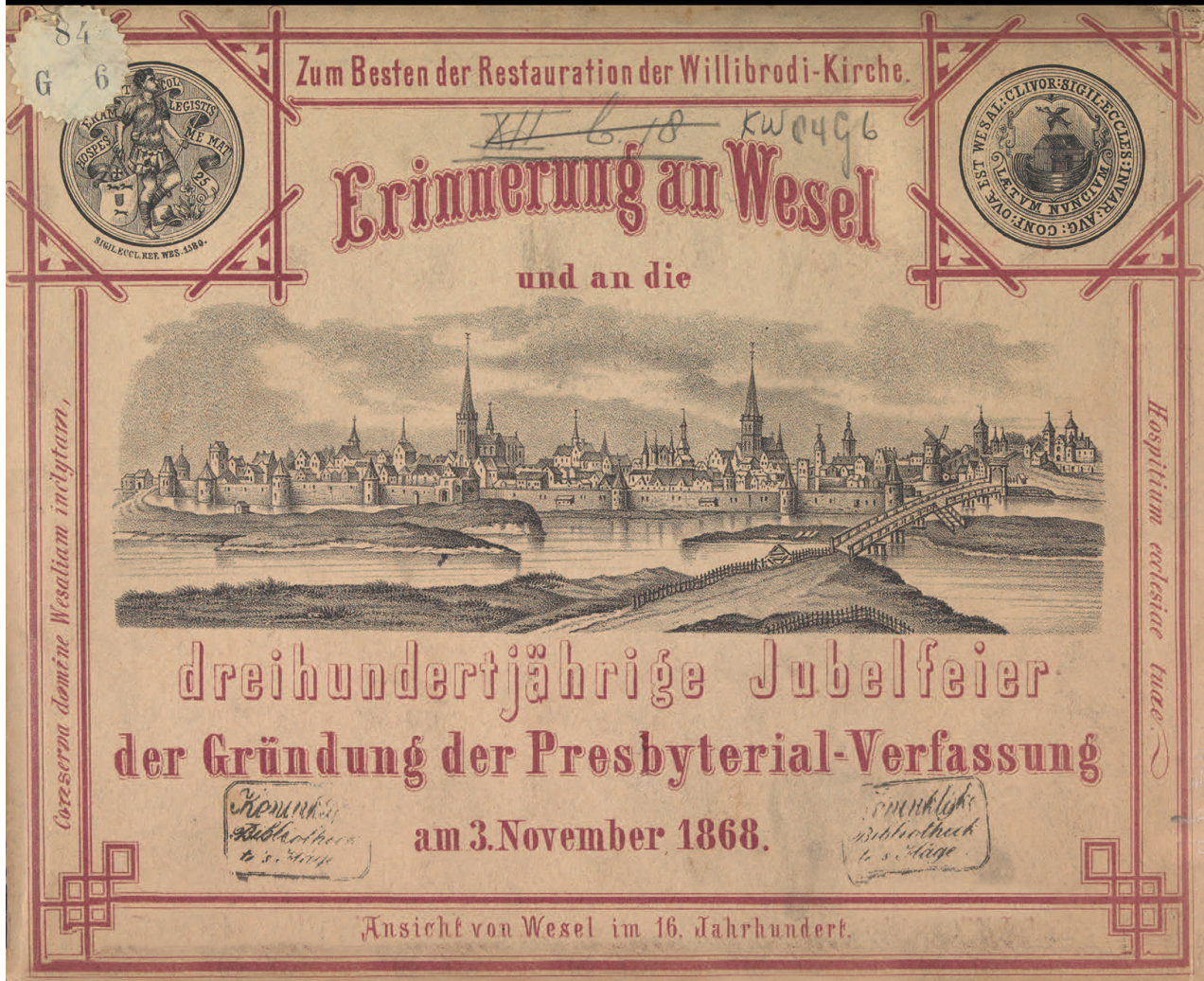

$\Delta$

Book cover of Jesse Spohnholz's The Convent of Wesel: The Event that Never was and the Invention of Tradition.

(C) Cambridge University Press. 
established in Germany and England, gathered in Wesel on 3 November 1568 and adopted 122 articles concerning worship and church government to be put into effect either immediately or 'after the Lord has opened a door for preaching of the Gospel in the Netherlands'. Although the situation in the Low Countries prevented their immediate adoption, they came with time to be understood as an important step toward a comprehensive, authoritative Dutch Reformed church order. What led historians to believe for centuries that a substantial assembly had drafted these articles was that the manuscript listing them concludes with the notation 'done at Wesel, November 3, 1568' and is followed by 63 signatures. The first historians and copyists to draw attention to this manuscript in the seventeenth century inferred from the signatures that the signees had met in Wesel and worked in the manner of a church synod, even though the document is simply headed 'Certain specific chapters or articles that in the service of the church of the Netherlands have been judged to be partly necessary and partly useful'. The word 'convent', deriving from the Latin conventus or assembly, displaced 'synod' in references to these articles in 1851, when some specialists in church law began to doubt that the meeting that they still believed had taken place had followed the procedures typical of a synod.

Spohnholz's outstanding first book on Wesel's distinctive religious history from 1559 to $1618^{2}$ alerted him to the fact that nothing in the city's well-preserved archives reveals a synod-like meeting in the town in November 1568 , nor does the correspondence of any of the signatories. Jan Pieter van Dooren had already observed the absence of contemporary references to a substantial gathering in Wesel and shown that certain signers of the document were elsewhere on 3 November 1568. Van Dooren and Owe Boersma had proposed alternative times or places for the meeting Antwerp in the winter of 1566-1567 in the former case, Wesel in July 1571 in the latter. ${ }^{3}$ Encountering these different views, Spohnholz set out to solve the mystery of the Convent. Following the tracks of earlier historians, he located and examined the six known manuscript versions of the Wesel articles, compared the articles with other early Reformed church orders to determine their distinctive features, and accumulated information about the signers, especially the two whose names appear first, Petrus Dathenus and Herman Moded. Finally, he reconstructed the situation, both political and ecclesiological, of the Netherlandish Reformed in early November 1568. Community in the Age of Religious Wars (Newark 2011).

3 Jan Pieter van Dooren, 'Der Weseler Konvent 1568: Neue Forschungsergebnisse', Monatshefte für Evangelische Kirchengeschichte des Rheinlandes

\footnotetext{
31 (1982) 41-55, summarized and discussed by Spohnholz, The Convent of Wesel, 201-208; Owe Boersma, Vluchtig voorbeeld: De Nederlandse, Franse en Italiaanse vluchtelingenkerken in Londen, 1568-1585 (Kampen 1994) 197-205, summarized and discussed by Spohnholz, The Convent of Wesel, 208-212.
} 
Spohnholz's powerful new contextualization of the articles suggests first of all that, pace Van Dooren and Boersma, November 1568 is a plausible date for their drafting and circulation. Although the years immediately after 1566 were dark times for the churches that had briefly taken shape in the Wonderyear, the summer and fall of 1568 was a moment of relative hope when William of Orange rallied support for a series of incursions meant to free the Seventeen Provinces from the 'tyranny' of the duke of Alva. It was thus a propitious time for pastors concerned with building a cohesive church on the model of the best Reformed churches of the time to define the practices they wished to implement should the incursions succeed. But rather than being adopted by a large gathering of people in Wesel, a possibility ruled out by the evidence that many important signers of the document were elsewhere, the articles were chiefly written by the man whose name appears first among the signers, Dathenus, with some assistance from signer number two, Moded, the former pastor of Antwerp then serving the Dutch church in Norwich.

Two distinctive features of the articles argue strongly for Dathenus's authorship. First, they devote extensive attention to the institution of the prophesying or profetie. Dathenus had previously served as a pastor in two churches, Emden and the Dutch refugee church of London, which had such an organization for training future pastors and promoting Biblical knowledge. Second, the articles insist on the fractio panis as an essential component of the Lord's Supper. Dathenus's most recent pastorate was in the Palatinate, where this practice had recently become a point of controversy ardently defended by the Reformed. The oldest manuscript of the Wesel articles, however, appears to be in Moded's hand. Dathenus and Moded are both known to have traveled to Switzerland in 1568. Spohnholz suggests that they met in Geneva and returned northward together, discussing en route how best to organize the churches of the Low Countries in the manner of those they admired in France, Geneva, the Palatinate and England. When they arrived in Wesel, Moded wrote up their points of agreement for Cornelis Walraven, a refugee minister originally from Brabant then living nearby whose signature appears third on the list. $\mathrm{He}$ became 'their local contact who helped the two more famous ministers share the manuscript with a few sympathetic men living in and around Wesel' (page 7o). Moded then took the document to Emden and London for more signatures. Finally, he deposited it among the papers of the Dutch refugee church in Austin Friars. Its signees included exiled pastors, elders, deacons, and some lesser nobles who may or may not have occupied Reformed ministries. Thirteen were either part of the Confederation of Nobles or closely tied to people who were. But many leaders of the Dutch exile communities in the Rhineland, East Friesland and England did not sign the document. It was not a statement of a consensus worked out by representatives of all churches and tendencies among the Netherlandish 
Reformed. Instead, as Juliaan Woltjer correctly saw in 1994, it was the platform of a pressure group. ${ }^{4}$

To me, these key conclusions seem thoroughly convincing. So too is the main point of the final chapter of Part One, devoted to the immediate impact of the Wesel articles, namely that they were of little or no consequence for the development of Dutch Reformed church institutions for at least fifty years. Three years after they were drawn up, a gathering that can confidently be said really to have taken place convened in Emden. The acts of this assembly make no reference to the Wesel articles, nor do they replicate many of their distinctive features. The acts of the earliest synods that subsequently met on the soil of the seven northern provinces after 1572 refer back to the Emden decisions but are equally mute about the Wesel articles. In publishing only the decisions of Emden 1571, Dordrecht 1578, Middelburg 1581, and The Hague 1586, the first printed edition of De Kercken-ordeninghen der Ghereformeerder Nederlandtscher Kercken (Delft 1612) appears correctly to have brought together the acts of four truly comparable synodal gatherings, three held in the Northern Netherlands after 'liberation' and one in an exile center prior to it. All four were part of a coherent, interconnected process of institutional development to which the Wesel articles appear extraneous.

While this is persuasively demonstrated, two misleading statements in this chapter deserve highlighting. First, Spohnholz notes that the Emden articles begin with a statement that is not found in the Wesel document declaring that no church, minister, elder or deacon may claim supremacy over any other. He speculates, ' $[t]$ his article may have been supported by those who had grown resentful of efforts by Dathenus and leaders in the Palatine church to speak for the Reformed movement as a whole' (page 101). A few pages farther along he asserts that 'in practice, building the Dutch Reformed Church was never a matter of applying a pre-prepared model. It was, rather, the outcome of decisions made within the immediate context of the years after 1572' (page 103). In fact, the principle of equality between churches and ministers asserted at Emden had already been adopted seven years previously by the synod of Netherlandish churches that met in Antwerp on 1 May 1564, one of the gatherings that Dutch church historical tradition would subsequently label 'Walloon synods under the cross' but that in fact brought together representatives from most or all of the few churches existing at the time, then overwhelmingly concentrated in the southern provinces. The 1564 Antwerp resolution was in turn a verbatim copy and expansion of the first article adopted at the initial national synod of the French Reformed 


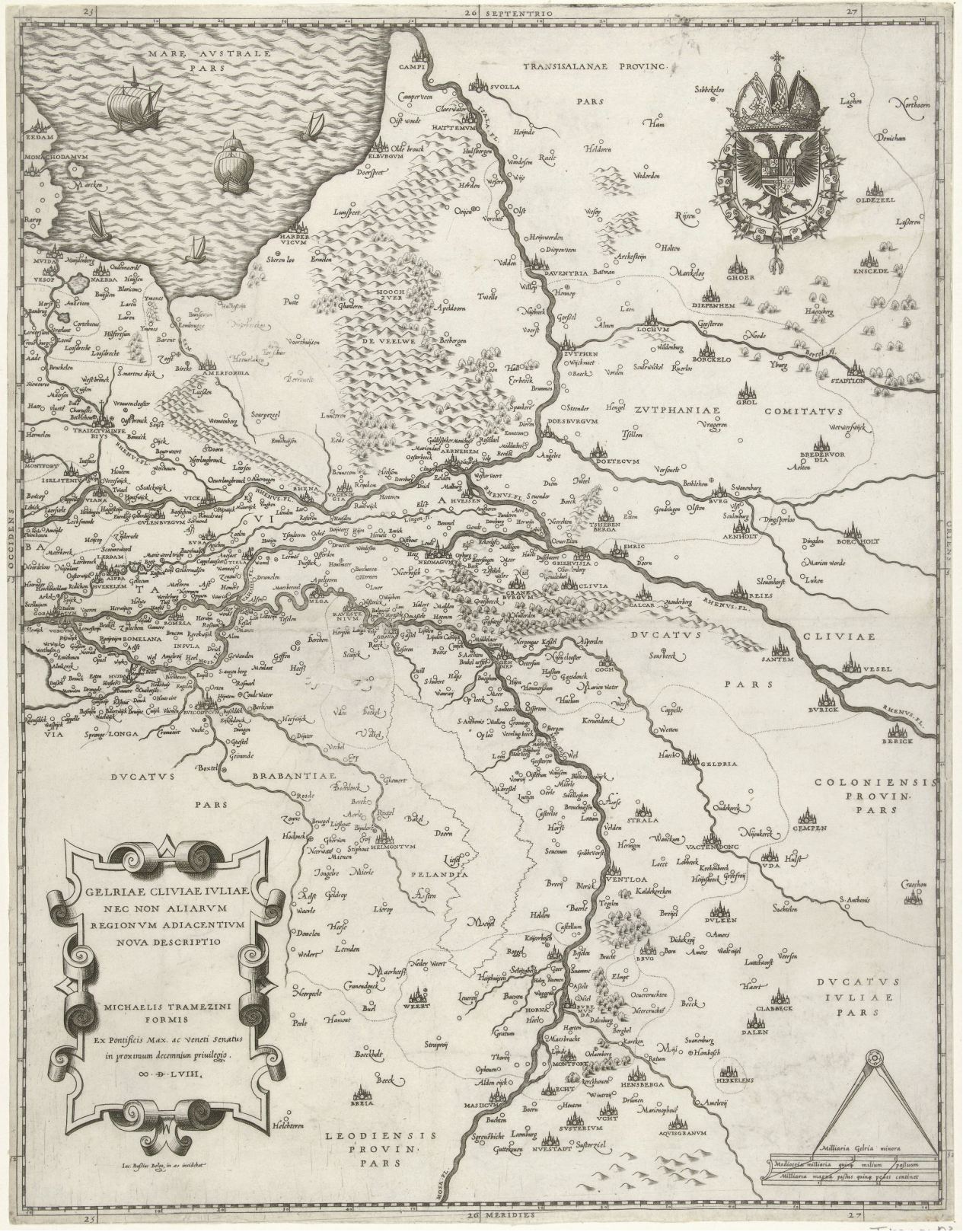

$\Delta$

This map of Gelderland drawn by Jacob Bos and Jacob van Deventer in 1568 - the very same year the Convent of Wesel allegedly took place - also depicts the city of Cleves and Wesel. (c) Rijksmuseum Amsterdam, RP-P-BI-2757, http://hdl.handle.net/10934/RMOoo1.COLLECT.443121. 
churches held in Paris in $1559.5^{5}$ The principle can be deemed nothing short of the foundational axiom of what is typically called the presbyterial-synodal form of church government, since it eliminates the sorts of hierarchies among churches found in episcopal systems or where rural churches are subordinated to the oversight of the pastors of a dominant city. The Emden decision was not simply a reaction against the pretentions to authority of Dathenus or anybody else in the 1570s; Dutch Reformed church building owed a debt to a preprepared French Reformed model and began with decisions taken at synods prior to 1566 , as Spohnholz recognizes earlier on in the book (pages 17-18) but does not underscore sufficiently here or subsequently.

\section{The Making and Unmaking of a Historical Myth}

If no church meeting took place in Wesel on 3 November 1568, and if the Wesel articles were not initially recognized as normative for the Dutch Reformed churches, when and how did historians come to believe that an important meeting had taken place in the Cleves town that helped mold later Dutch church practice? Part Two's detailed history of the construction and erosion of this invented 'mythistory' over four centuries is as fascinating as Part One's unraveling of the mystery of the Wesel articles is convincing. It appears that the ur-copy of the Wesel articles sat neglected in the Dutch church of London for nearly fifty years until its Contra-Remonstrant pastor, Simeon Ruytinck, found it in the church's archive and cited it as a set of synodal decisions in the Harmony of the Netherlandish Synods, prepared for the synod of Dordrecht and published in both Latin and Dutch. Dutch church bodies and German territories soon requested copies. Trigland's Ecclesiastical Histories (1650) and Voetius's Politica Ecclesiastica (1663-1673) referenced it. By 17361737 belief in the existence and importance of a Wesel synod was so deeply rooted that when a committee appointed by the provincial synod of South Holland set about organizing its collection of 'synodical books and writings', the chief cataloguer of these documents, the minister of Gouda and acting president of the synod, Quintinus Noorthbergh, labeled the manuscript stored in The Hague 'Authentic Synodal Acts from Wesel Anno 1568' and bound it together with copies of the subsequent synods already recognized as authoritative. The document had been canonized as the decisions of one of the foundational assemblies of the Dutch Reformed church. 
Noorthbergh's role in this story inspires Spohnholz to conclude the first chapter of section two with a series of larger reflections of unequal persuasiveness about the ways in which archives and archivists shape perceptions of history. Astutely enough, he remarks that institutions typically preserve records that legitimate their existence and power. Hence, archives are 'as much about ensuring [...] the future as [...] about recording the past' (page 142). In a point of considerable significance for understanding the subsequent historiography of Dutch Reformed church building, he points out that the documents that Noorthbergh placed in or omitted from the file of national synodal acts obeyed an implicit understanding of what was and was not Dutch shaped by the post-Revolt boundaries of the Republic. The acts of the underground synods held in the Southern Netherlands between 1562 and 1567 were excluded. 'Quite possibly, since their records were written in French, he considered them irrelevant to the Dutch public church' (page 143).

Less convincingly, Spohnholz casts the organization of the synodal archive as part of a larger 'eighteenth-century proliferation of archives across Europe' and takes it to reveal certain intrinsic characteristics of these 'new institutions'. 'The evidence preserved in these new institutions was hardly an objective collection of primary sources', he writes (page 142):
Archiving material [...] necessarily (italics in the original text) involves the process of forgetting certain elements of the past as much as remembering others [...]. The privileging of records relating to the construction of church institutions necessarily left out all sorts of other evidence from the history of the Reformation. It was firstly a gendered act, privileging the actions that only men were permitted to perform as worthy of remembering. It also marginalized heterodox, dissenting, or less dogmatic believers within the church. In short, it had the effect of flattening the history of the Reformation into a relatively two-dimensional, linear history of institutions, whose historical significance was taken for granted (page 143)

In pivoting so quickly to depict archives as active agents of history that express an imagined order of things, reinforce the claims of dominant groups, and silence the marginal, Spohnholz aligns himself here with a current within the recent surge of interest in the history of archives, stimulated by Michel Foucault's The Order of Things and Jacques Derrida's Archive Fever: A Freudian Impression. ${ }^{6}$ But in slotting his story into this prefabricated narrative according to which the new archives of the eighteenth and nineteenth centuries acted as instruments of power, he shoots right past the actual dynamic that led the Dutch Reformed churches to constitute the specific archives central to his tale well before the eighteenth century. The

6 Elizabeth Yale, 'The History of Archives: The State of the Discipline', Book History 18 (2015) 332-359, offers an excellent overview of recent work in this domain. Dol: https://doi.org/10.1353/bh.2015.0007. 
presbyterial-synodal form of government they adopted generated archives by its very nature from its earliest years. Why? Because the representatives of individual congregations who assembled in the first synods and classical assemblies did so to establish unity of doctrine and a common set of institutional and liturgical norms among the churches then beginning to multiply. For this to happen, it was imperative that the decisions of these gatherings be made known to every affiliated congregation and preserved for future reference. Already in late 1563 , one of the first underground synods of the churches of the Low Countries meeting in Antwerp specified that the decisions taken in each colloque should be read aloud at subsequent assemblies 'so that nobody is ignorant of the articles adopted for the benefit of the church'.7 Resolutions of the 1571 Emden synod asked every delegate to a provincial synod to carry home a signed copy of the articles adopted there. ${ }^{8}$ By the seventeenth century, the Walloon churches expected each congregation to have a compilation of synodal decisions that could be placed at the disposal of any church assembly meeting there. After discovering in 1640 that not every church had such a book, those lacking them were instructed to fill the lacuna by copying the volume of a nearby church. Twelve such compilations still existed in manuscript in the archives of individual surviving Walloon churches at the end of the nineteenth century, when the Commission de l'Histoire des Églises Wallonnes set out to produce the first printed edition of these acts. ${ }^{9}$

Nor, it should be pointed out, were livres synodaux the only documents that Reformed churches organized along presbyterial-synodal lines were expected to keep. In the case of the French Reformed churches, whose sources I know better, the very first proto-synod of 1557 instructed the elders and deacons of each congregation to maintain and preserve lists of church members, registers of baptisms and marriages, and volumes of consistorial decisions. ${ }^{10}$ The Dutch churches came to keep the same kinds of registers. The chief impetus behind the archiving impulse of the Reformed churches was to preserve the record of this self-governing church's past institutional actions. While Spohnholz went to great effort to examine the known copies of the Wesel articles and trace their archiving over the centuries, he did not explore this larger context of record-keeping within the churches. Had he done so, he might have been less quick to assert that the constitution of these archives silenced heterodox believers and privileged the actions of men, given that both synodal deliberations and consistory registers provide some of the best sources available

Acta van de Nederlandsche Synoden der zestiende eeuw, Werken der Marnix-Vereeniging, 1st ser., vol. 4 (The Hague 1889; repr. Dordrecht 1980) 108, 112-113.

Livre synodal, 6.

Livre synodal, 15-16; Frederik Lodewijk Rutgers (ed.), Livre synodal, preface, 6 .
10 On record-keeping in the French Reformed churches, see Philip Benedict and Nicolas Fornerod (eds.), L'organisation et l'action des Églises réformées de France (1557-1563). Synodes provinciaux et autres documents (Geneva 2012) XVII-XXVIII. 
for detecting heterodox opinions, that consistory registers record the voices of female church members better than any other kind of church document, and that in the hands of historical demographers registers of baptisms and marriages have yielded fundamental information about basic aspects of women's lives such as the frequency of childbirth and maternal mortality.

Interest in the Wesel Convent only grew in the nineteenth century, as borders, constitutions, and national church regulations all changed several times in both the Low Countries and the Rhineland. Each change sparked research and debate about local church traditions. Dutch neo-Calvinists such as the historian Guillaume Groen van Prinsterer and the theologian and politician Abraham Kuyper claimed major importance for the Wesel Convent. Advocates of a broad national church downplayed its influence. According to Spohnholz, a caesura then came with 'the new academic history writing of the late nineteenth century, whose focus on original archival research and systematic scholarly methods made claims about the synod of Wesel nearly impossible to maintain' (page 188). In fact, despite the conviction of the nineteenth-century champions of new, more methodical and more archivally based methods of historical research that theirs was the royal road to greater accuracy, it took an awfully long time for belief that a synod-like gathering took place in Wesel to erode.

When Frederik Lodewijk Rutgers, professor of church history at the Vrije Universiteit Amsterdam (vu), edited the acts of the Dutch synods of the sixteenth century for the Marnix Society in 1889 , he realized the absence of contemporary evidence for such a gathering, headed his transcription of the 1568 document 'articles of the meeting [not 'synod' or 'convent'] at Wesel', and called it simply a set of points advocated by a number of Dutch church servants in his brief introduction to it. Nevertheless, he perpetuated the practice of Ruytinck and Noorthbergh of placing the Wesel articles among the synodal decisions. Indeed, he put them first in line. ${ }^{11}$ The prominence given to them more than counterbalanced the corrosive effects of his discreet re-labeling of the document. A vu dissertation written twenty years later by Jan de Jong on the Convent of Wesel reiterated the myth of the meeting and repeated such shaky assertions about it made by earlier historians as that it assembled 63 men and lasted several days under Dathenus' chairmanship. ${ }^{12}$ The standard works of church history or law to emanate from Dutch Reformed theology faculties over the next generations continued to make the Wesel Convent act one in the process of Dutch church-building, even though the

Rutgers, Acta, 1-41, especially page 1; Spohnholz, The Convent of Wesel, 193-194. In Rutgers' volume the Wesel articles are followed by those from Emden, Dordrecht 1574, Dordrecht 1578, Middelburg 1581 and The Hague 1586.
12 Jan de Jong, De voorbereiding en constitueering van
het kerkverband der Nederlandsche Gereformeerde Kerken in de zestiende eeuw: historische studiën over het Convent te Wezel (1568) en de Synode te Emden (1571) (Groningen 1911), discussed by Spohnholz, The Convent of Wesel, 194-195. 
Göttingen Privatdozent Hermann E. von Hoffmann had properly accorded the French and 'Walloon' synods central position in this process in the opening section of his 1902 Das Kirchenverfassungsrecht der niederländischen Reformierten bis zum Beginne der Dordrechter Nationalsynode von 1618/19. ${ }^{13}$ For two generations or more, unconscious confessional and national blinkers continued to incline post-Rankean Dutch historians to accept an interpretation of the Wesel articles made centuries previously and given added plausibility by the manner in which the document was archived.

Clear recognition of the erroneous character of assertions such as those found in De Jong's 1911 dissertation really only gained strength in the last third of the twentieth century. What sparked this recognition, ironically enough, was the organization of the 4ooth anniversary commemoration of the non-event in 1968, for it was while putting together an exhibition for this commemoration that Van Dooren, the archivist of the old Dutch Reformed Church archives, realized how scant the evidence was that the signers of the Wesel articles actually gathered in the city in 1568. He kept tugging at the evidence for fourteen more years before arriving at his hypothesis that the articles were the product of a synod held secretly in Antwerp in late 1566 or early 1567 . The supposed event had been problematized. Commemorative conferences may seem to some academic historians to be annoying interruptions that call them away from ongoing research projects to respond to a memorial impulse about which they may be ambivalent. This case suggests they can also reinvigorate the study of a neglected topic by summoning researchers to take a look at it again. Even then, the topic was little pursued until Spohnholz latched onto it, since it stood far from the social historical concerns that dominated the study of Reformation history from the 1970 onward.

\section{Conclusion and Implications}

Having led the reader patiently through the complexities of the Wesel articles, the history of their surviving manuscript copies, and the historiography of the assembly that never was, Spohnholz ascends into the meta-sphere in the Conclusion. Spohnholz's doubts about the epistemological claims undergirding academic history had already begun to crop up late in Part Two, where a brief introduction to Humboldt and Ranke as arch-apostles of academic history gave rise to the observation: 'Of course, [their] optimism about objectivity was an illusion'. Not only were the gereformeerde kerkorde in de Nederlanden', in: De historie herzien. Vijfde bundel 'Historische avonden' uitgegeven door het Historisch 
archives whose authority they exalted 'as much of an instrument of power in controlling history as [...] a resource for unlocking the past'; 'the passion for truth celebrated by scientific historians corresponded to a certain set of cultural norms that necessarily excluded [...] women, atheists, Jews, and peasants' because doing original research in Reformation history required an education in Latin, theology, and paleography that only upper- and middle-class male Christians received at the time (page 191). The Conclusion is replete with such doubts. In one section Spohnholz asks 'Can any of us separate ourselves from our own context enough to ever offer an objective, complete, and accurate understanding the past?' (page 235), laying a heavy burden on himself and his fellow historians with his coupling of 'objective' and 'complete' to 'accurate'. The question arises from his personal awareness that the two parts of his book stand in tension with one another. Part Two shows that what previous historians wrote about the Convent of Wesel was deformed by archival mis-labelling and their own presuppositions. Part One claims to set out a more accurate account of what did and did not happen. How can he be sure that his own interpretation is not equally enmeshed in the snares of subjectivity?

As a prophylactic, he spells out his own situatedness so that readers can at least make allowances for it. Strikingly, he speaks of his Alaskan upbringing and his current place in the internet-wired knowledge production system of the contemporary research university, but he says nothing about his intellectual formation as a historian, although both the book's neoFoucauldian ideas about power/knowledge and its preoccupation with confessionalization seem to me its most distinctive features and ones that mark it as a product of a specific moment in American graduate training in Reformation history.

Another section grapples with more abstract questions in the philosophy of history. 'The past is fundamentally unknowable (italics in the original text) to us in the present, at least in a complete sense' Spohnholz initially asserts here. He believes that this is so for two reasons. First, the evidence about the past, 'no matter how voluminous, is inevitably incomplete'. Second, 'the very categories of analysis that we use to understand the past are fundamentally estranged from the world of the sixteenth century' (page 228). The concepts chosen to illustrate this latter point are 'Reformation' ('an interpretative framework, developed retrospectively, that asserts that something coherent happened in the history of Christianity starting in 1517') and 'confession' - in fact, terms widely employed by sixteenth-century actors. He then backpedals from the most sceptical implications of the second point. 'I'm not claiming that historians should abandon analytical categories to describe the past. After all, language is always incapable of capturing the complexity of the world, and yet we still need it to communicate. What I am claiming is that historians should not a priori adopt categories promoted in one context by interested parties with specific confessional goals and apply 
them to other contexts, particularly in cases where the evidence shows that people rejected or ignored categories or crossed the boundaries between them with relative ease' (page 231). That most historians who use these terms apply them to inappropriate contexts is never demonstrated.

The book ends with four main conclusions. 'First, the story of the Convent of Wesel reminds us just how complex and contingent human history is'. Secondly, confessional ambiguity reigned during the Reformation era. 'Third, historical research should be conducted mindful of the ways that context shapes our research and writing'. Fourth, archives embody complex inheritances from the past 'that are not neutral and objective' (pages 240241).

With the book's ambitions scaled all the way up to what it 'can teach us about what it means to study the Reformation, as well as history itself', these conclusions are disappointingly banal. The first could be said of the history of any event studied in detail. The second is not only one of those broad statements that is true except insofar as it is untrue; it is beside the point of the book's most important positive findings about the authorship and reception of the Wesel articles. In either its weak form associated with Ernst Walter Zeeden, or its strong form associated with Heinz Schilling and Wolfgang Reinhard, confessionalization has always been understood as a long-term process by which the 'magnificent anarchy' of the early evangelical movement gave way over time to clearly specified rival doxas communicated to the mass of ordinary church members through education, acculturation, and governmental constraint. The Convent of Wesel, however, concerns a proposed church order for the Netherlands in the decade when the normative confession of faith and church structures for the Reformed of the region were first being defined. That competing ideas and platforms about how to structure a new church existed in the decade of initial confessional definition neither surprises nor seems to nuance what even the most enthusiastic advocates of either version of confessionalization would have claimed. Conclusions three and four are commonplaces about historical method that could only seem worth stating to a person who believes that most previous historians were oblivious of how their context might shape their work or thought the archives they visited to be objective collections of materials, whatever objective might mean in that phrase.

Were earlier generations of historians really that naive? It is easy to understand how Spohnholz might have come to think they were. Anybody who has remotely followed recent debates about the nature of historical knowledge knows that theories emphasizing the subjectivity or even arbitrariness of individual attempts to write history have gained enormous visibility over the past forty years. Assertions such as Hayden White's famous formulation that 'historical narratives are verbal fictions, the contents of which are as much invented as found and the forms of which have more in common with their counterparts in literature than they have with those 
in the sciences', have hardly gone unchallenged. ${ }^{14}$ Yet as discussion has swirled around such claims, the views of their advocates have garnered more attention than those of their critics. Open-minded commentators have come to see the most useful insights of writers such as Foucault, Derrida and White as bringing historical practice to a new level of critical consciousness. In so doing, they have bought into a narrative of the history of ideas about historical method pushed by the most enthusiastic acolytes of these theorists according to which the great majority of historians were uncritical empiricopositivists before these thinkers highlighted the constructed nature of documents, archives, and historical writing. Thus, Sarah Maza's recent, measured Thinking About History asserts that the debates of the last few decades have so changed the discipline that it is now 'impossible to imagine going back to a time' when 'most historians assumed that a scientifically examined source could yield only one meaning' and believed 'that the study of the past wholly free of the distortions of personal bias or belief was both desirable and possible'. ${ }^{15}$ Alexandra Walsham, one of the finest contemporary cultural historians of the Reformation, introduces a recent collection of essays on the history of archives and archiving with the comment, 'the tendency to regard archives as neutral and unproblematic reservoirs of historical fact is a legacy of the historiographical developments of the nineteenth century'. 'We still fall into the trap of approaching [sources] as if they provide a transparent window through which we can view societies remote from us in time'. ${ }^{16}$

Such depictions of the theory and practice of history before postmodernism are simply off the mark. Nobody ever reads manuals of historical method written before they were students, but those who write about the history of historiography should, for they offer an excellent antidote against condescension toward our historian ancestors. Langlois and Seignobos' Introduction to the Study of History, the most widely used such work in both France and the United States for several generations, did not teach a naive correspondence theory version of empiricism according to which historians go into the archives, read documents, and write up what they find as if the documents were transparent windows into the past yielding only one meaning apiece. It taught that writing history involved a combination of analytic and synthetic operations: subjecting sources to internal and external

Hayden White, 'Historical Texts as Literary Artifacts', in: Hayden White, Tropics of Discourse: Essays in Cultural Criticism (Baltimore 1978) 82. For a particularly incisive critique of the position articulated by White in this volume of essays and in his Metahistory, see Lionel Gossman, 'Towards a Rational Historiography', Transactions of the American Philosophical Society 79:3 (1989). DOI: https://doi.org/10.2307/3137417.
15 My paraphrase here melds quotations found in Maza, Thinking About History, 201 and 233.

16 Alexandra Walsham, 'The Social History of the Archive: Record-Keeping in Early Modern Europe', in: Liesbeth Corens, Kate Peters and Alexandra Walsham (eds.), The Social History of the Archive: Record-Keeping in Early Modern Europe. Past \& Present Supplement 11 (2016) 9. DoI: https://doi. org/10.1093/pastj/gtw033. 
criticism to extract from them the many 'conceptions and statements as to facts' that each one suggested; corroborating or rejecting these on the basis of a similarly critical analysis of complementary documents; and shaping the inferences that survived the winnowing process into the declarative statements that actually composed a work of history. ${ }^{17}$ Although the book did not explicitly urge historians to exercise the same instincts of Quellenkritik in thinking about archives as in thinking about individual documents, it is hard to imagine any historian working for a long time in an archive without asking 'For what purpose was the archive created?' and 'Why did this series end up in it?'. In the ongoing dialogue between the more subjectivist and more objectivist positions that has characterized writing about historical method since Langlois and Seignobos, no advocate of the latter position to my knowledge has ever claimed that everything about a historical topic could be completely known. Objectivity's defenders have always considered this an ideal to strive toward, not a condition that fallible mortals can perfectly attain. Even G.R. Elton, the most vigorous defender of the position that 'exact knowledge' is possible about many well-documented past events, wrote,

\begin{abstract}
the methods of the trained professional historian are designed to protect him against his human difficulties, and they very often do achieve their purpose. Naturally, they do not render him immune to error, nor do they automatically eliminate bias and inadequacy, or the simple problems of time and space which hinder full or fully accurate knowledge. History is an unending search for truth, with the only certainty at each man's end that there will be more to be said and that, before long, others will say it. ${ }^{18}$
\end{abstract}

As for the assertion that the methods of scientific history elaborated by its first proponents were not objective since they corresponded to cultural norms held in the nineteenth century only by elite male European Protestants, the logical fallacy of evaluating the general validity of abstract propositions about epistemology on basis of the contingent sociological characteristics of those who first proposed them should be obvious. There is no reason why the methods of academic history and the linguistic skills required to read the Wesel articles that were initially the cultural capital of middle- and upperclass male European Christians could not be learned by women, atheists, Jews and peasants, as indeed they soon were once access to universities widened.

It may seem excessively harsh for this review to press so hard on Spohnholz's statements about historical objectivity and the knowability of the past. As Peter Novick has observed, a great deal of what practicing 
historians have written over the past century about the objectivity question has been confused. This is 'not a crime; not even blameworthy', since 'very few historians have any philosophical training, or even inclination'. ${ }^{19} \mathrm{~A}$ book that devotes half of its attention to the history of scholarship and aspires to articulate conclusions that illuminate the nature of historical inquiry itself ought nonetheless to display a better knowledge of the philosophy and practice of history.

What is particularly unfortunate about the Conclusion's less than satisfactory examination of the biggest meta-questions is that it comes at the expense of any reflection about the implications of Part One's positive findings about the Wesel articles for the broader topics within the history of the sixteenth century to which they are pertinent. If we grant that the articles were written chiefly or exclusively by Peter Dathenus, not collectively determined by a larger assembly of Reformed churchmen, that they were extraneous to the chain of decisions that built the Dutch Reformed church's initial rules for how it would like to operate, and that an inappropriate back-projection of later national boundaries led historians from Ruytinck to Rutgers erroneously to exclude the acts of the first 'Walloon' synods from that chain of decisions, how does that change our comprehension of the politics and process of the Netherlandish Reformation? This is a question that Spohnholz's expertise would have equipped him much better to handle, but that he never explores.

Since he did not do so, let me briefly suggest three avenues for future research suggested by his findings. First, historians of Dutch Reformed church-building need to devote renewed attention to the years from 1561 to 1566 , to the synods under the cross held in this period in the Southern Netherlands, and to the cross-border movements and connections with France that explain why almost seventy percent of the 48 articles adopted at the May 1564 synod in Antwerp were copied or adapted from decrees of prior French national synods. The construction of the church's institutions and rules of operation was a cumulative process that was already well underway before the first synod to gather within the territory of the future Netherlands met. The French-Walloon connection had an importance for this process and for other key aspects of the early development of the Reformed church in the Low Countries that remains far less well elucidated than the influence of Emden and London as model churches and exile centers.

Second, The Convent of Wesel's highlighting of the enduring errors that mis-cataloguing documents or publishing an inappropriately selected sample of them can induce highlights the need for a good new critical edition of the Dutch synodal acts. This should include not only the synods under the cross prior to 1566 and those edited by Rutgers for the remainder of the sixteenth century, but also the far larger selection of church orders and synodal decisions 
from the seven provinces of the Republic provided in Cornelis Hooijer's 1865 Oude kerkordeningen der Nederlandsche hervormde gemeenten (1563-1638). ${ }^{20}$

Finally, recognizing Dathenus as the principal or sole author of the Wesel articles gives us a detailed statement of his views about church institutions and liturgical practices circa 1568 to add to his limited corpus of writings. Few life stories in the entire history of the European Reformation are more fascinating than that of this ex-Carmelite of Ypres who emerged as Ghent's fiercely militant minister in both the Wonderyear and the era of the 'Calvinist republics', only to grow disillusioned after the collapse of the Hembyze regime, flirt with the ideas of David Joris, and end his life as a schoolteacher in Elbing. His life and thought deserve further examination. One regrets that Spohnholz, who in so many other ways has illuminated the situation of the Netherlandish Reformed in the later 1560 , did not provide this.

Philip Benedict is Professor Emeritus at the Institute for Reformation History of the University of Geneva. Among his many publications are two that examine the institutional history of Europe's Reformed churches: Christ's Churches Purely Reformed: A Social History of Calvinism (2002) and (edited with Nicolas Fornerod), L'organisation et l'action des Églises réformées de France (1557-1563). Synodes provinciaux et autres documents (2012). His most recent book, Season of Conspiracy: Calvin, the French Reformed Churches, and Protestant Plotting in the Reign of Francis II (1559-1560), appeared from the American Philosophical Society Press in 2020. E-mail: Philip.Benedict@unige.ch. Nederlandsche hervormde gemeenten (1563-1638) en het concept-regiment op the organisatie van her Hervormd kerkgenootschap in het koningrijk Holland (1809) (Zaltbommel 1865). The need for a new edition of the Walloon synods under the cross was already noted fifty years ago by Gérard Moreau, 'Les synodes des Églises wallonnes des Pays-Bas en 1563', Nederlands Archief voor Kerkgeschiedenis, n.s., 47 (1965-1966) 1-11. 